\title{
STRATEGY DEVELOPMENT SMALL MIDDLE ENTERPRISE TEMPE BANG JARWO AT SURABAYA WITH BUSINESS MODEL CANVAS APPROACH
}

\author{
Muh. Asrori Afandi \\ Universitas Airlangga
}

\begin{abstract}
These days, the tight competition in small and middle enterprises gets them to rethink how to develop strategies that can grab the attention and hold the customers' hearts. This study aims to give recommendations for those enterprises such as Tempe Bang Jarwo to survive, develop, and compete against the other home industries by using the Business Model Canvas (BMC) approach. This study uses qualitative methods while formulating strategies by observing and using in-depth interviews and then analyzing them using SWOT and Business Model Canvas. The results of the studies are as follows; 1. Focus on selling the core product of tempe 2. Hold a workshop and business training 3 . Publish and sell Book 4. Be apart of CSR.
\end{abstract}

Keywords : Business Model Canvas; SME; Bang Jarwo's Tempe business strategy; SWOT analysis.

Coresspondence to : semangat.asrori@gmail.com

\begin{abstract}
ABSTRAK
Seiring berkembang nya waktu, ketat nya persaingan bisnis pada usaha umkm membuat mereka untuk berpikir kembali bagaimana strategi pengembangan yang mampu di terima dan mendapatkan posisi pada hati customer. Penelitian ini bertujuan untuk memberikan rekomendasi untuk UKM seperti Tempe Bang Jarwo untuk tetap bertahan, berkembang dan bersaing dengan industri rumahan lainnya dengan pendekatan Bisnis Model Kanvas (BMC). Penelitian ini menggunakan metode kualitatif saat merumuskan strategi dari observasi dan menggunakan wawancara mendalam, kemudian di analisa semua menggunakan SWOT dan Bisnis Model Kanvas. Hasil penelitian ini telah menemukan bahwa: 1. Focus pada penjualan produk tempe; 2. Membuat workshop dan trainig bisnis; 3 . Membuat suatu buku dan menjualnya; 4. Menjadi tempat penyaluran CSR.
\end{abstract}

Kata Kunci: bisnis model kanvas; UMKM; strategi bisnis tempe bang jarwo; analisa SWOT

\section{Riwayat Artikel:}

Received : 16 Desember 2020

Revised : 13 Januari 2021

Accepted : 25 Januari 2021 


\section{INTRODUCTION}

One of the government's strategies to build a sustainable economy is by empowering and growing micro, small, and medium enterprises (MSMEs) as a basis for community economic development. History has shown that MSMEs in Indonesia still exist and develop despite the economic crises in 1998 and 2008 (Tambunan 2019). The more MSMEs in Indonesia, the microeconomic growth will also increase. On the other hand, MSMEs also experience problems with limited working capital, low product quality, and simple technology(Ayodya 2020). Another dimension is related to the business planning that is carried out by MSMEs; in general, it is just how the trade products sell in the market right away. (Umar et al. 2018)

The development of MSMEs can also be seen in Surabaya, especially in the Dolly area, Banyu Urip. Dolly is one of the localization areas that was closed by the Surabaya government in 2014.(Hakim 2014) The government has also provided various alternative ways to change for the better by providing training for residents to become entrepreneurs of small and medium enterprises (SMEs). One such SMEs is Bang Jarwo, which sells tempe (food from soybean).

Bang jarwo is one of the products of SMEs that still survive, develop, and exist selling around Surabaya. Tempe is a very popular snack with the public, and it is common for many culinary businesses to use tempe as a main or additional product in the food menu.

Bang Jarwo's SMEs tempe business from year to year has grown even though its income is uncertain. Currently, the tempe business competition is getting tougher because of the large number of home-based tempe industries in Surabaya and its surroundings. Various tempe in traditional markets and supermarkets are also very diverse, ranging from very low prices to having good brands and packaging. The researcher have conducted a survey by distributed questionnaires to 100 informants in West Surabaya randomly with the critecia of having purchased tempe product in supermarkets, traditional market and mobile tempe traders.

TABLE 1. Competition for Bang Jarwo tempe

\begin{tabular}{|c|c|c|c|c|}
\hline Brand & $\begin{array}{l}\text { Tempe Bang } \\
\text { Jarwo }\end{array}$ & Hienak Tempe & $\begin{array}{l}\text { Tempe } \\
\text { Malang }\end{array}$ & $\begin{array}{l}\text { Regular tempe } \\
\text { (unbranded) }\end{array}$ \\
\hline Price & $\begin{array}{l}\text { Rp. } 1,000 / \\
\text { plastic packs }\end{array}$ & $\begin{array}{c}\text { Rp. } 2,500 / \\
\text { plastic packs }\end{array}$ & $\begin{array}{c}\text { Rp. 8,000 / } \\
\text { plastic } \\
\text { packs }\end{array}$ & $\begin{array}{c}\text { IDR } 2,500- \\
5,000 / \text { piece }( \pm \\
15-30 \mathrm{~cm})\end{array}$ \\
\hline $\begin{array}{l}\text { Distributi } \\
\text { on } \\
\text { channel }\end{array}$ & $\begin{array}{c}\text { Direct selling, } \\
\text { the vegetable } \\
\text { seller }\end{array}$ & Direct selling & $\begin{array}{l}\text { Supermark } \\
\text { ets, } \\
\text { traditional } \\
\text { markets }\end{array}$ & $\begin{array}{c}\text { In the } \\
\text { traditional } \\
\text { market, the } \\
\text { vegetable } \\
\text { seller. }\end{array}$ \\
\hline Features & $\begin{array}{c}\text { Plastic and } \\
\text { with a sticker, } \\
\text { there is a } \\
\text { mobile } \\
\text { number. }\end{array}$ & $\begin{array}{l}\text { With a sticker, } \\
\text { there is a halal } \\
\text { logo, a PIRT } \\
\text { logo, and an } \\
\text { expiration date. }\end{array}$ & $\begin{array}{c}\text { Paved, and } \\
\text { with a } \\
\text { sticker }\end{array}$ & $\begin{array}{c}\text { Banana leaves / } \\
\text { just a feature. }\end{array}$ \\
\hline $\begin{array}{c}\text { Market } \\
\text { share }\end{array}$ & $14 \%$ & $22 \%$ & $18 \%$ & $46 \%$ \\
\hline
\end{tabular}

Source : survei

With the very high competition in the culinary business, the SMES should make new innovation (Sudrajat et al. 2018). Bang Jarwo's SMEs tempe must open the hearts of customers in Surabaya to win the competition in the tempe side dish food business in Surabaya.

From this background, the researcher wants to formulate a problem formulation about developing a marketing strategy for Jarwo tempe in the tempe business market competition? This study aims to provide recommendations to help SMEs Bang Jarwo as small SMEs continue to grow and compete with other home tempe industries. We will learn more about business strategies to develop Bang Jarwo's smallmedium tempe business through the SWOT analysis approach and the canvas business model from the explanation of these problems. The use of the business model canvas illustrates the overall business model and the interconnection between the more attractive parts and will provide solutions for SMEs' competitive strategy (Marfuah, Nopianti, and Ambaria 2019).

According to Freddy Rangkuti (2006), SWOT analysis is the systematic identification of various factors to formulate a company strategy. This analysis is based on a logic that maximizes strengths and opportunities, but at the 
same time, minimizes weaknesses and threats. (Rangkuti 2015)

According to Alexander Osterwalder \& Yves Pigneur (2012), a business model describes the rationale for how organizations create, deliver, and capture value. One of the business models initiated by Alexander Osterwalder \& Pigneur, (2012) is the canvas business model, a business model that describes a business model that is thoroughly broken down by describing the organization, competitors, and the market. This canvas business model consists of 9 building blocks interconnected and become the basic system for creating strategic alternatives.

The nine blocks include (a) the Customer segment, explaining that customers are the main key to getting profit; without customers, a company cannot last long. Customer segment will classify which customers want to be selected into a profitable target market for the company; (b) Value proposition, explaining that a product and service has a value solution to customer problems and provides customer satisfaction (Alexander Osterwalder et al., 2019); (C) Channels, explains how a company can communicate with its customers in conveying its value proposition. There is a distribution process that will be used to deliver products and services to customers; (d) Customer relationship, describes the relationship with customers that is built following the characteristics of the customer segment; (e) Revenue stream, describes the company's revenue stream that gets from each customer; (f) Key resources, describes what resources are owned and support the business process; (g) Key activities, explaining related to important activities that the company should do so that the business it is doing can work well; (h) Key partnership, describes the existence of a collaboration with other parties to optimize business, reduce risk, and to have high sanity with its competitors; (i) Cost structure, describe the cost structure needed to run a business model. (Alexander Osterwalder and Pigneur 2012).
Figure 1. Business Model Canvas

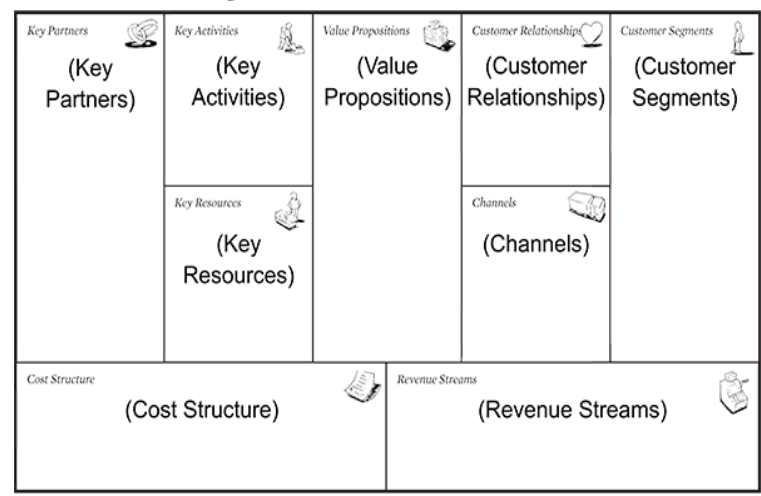

\section{METHODS}

The research method is a method or method that is arranged systematically and clearly in the research process (Sugiyono 2010). The aim is that research can be carried out more focused so that research can be achieved and makes it easier to analyze existing problems. This type of research uses in-depth interviews and direct observation to obtain primary data and find out about the profiles of SMEs and organizational structuring to obtain additional data.(Zikmund 2013).

Interviews were conducted from September 2019 to January 2020. The determination of informants was based on the snowball technique, which is a method for identifying, selecting and taking samples in a continuous network or chain of relationships (Neuman 2003). The informant who had been interviewed totaled 15 people among its namely (1) Bang Jarwo (key informant), (2) a companion SMEs dolly, (3) customer households and traders culinary penyetan, (4) a seller of soybeans, (5) the student organization Unair, (6) lecturer in entrepreneurship study program, (7) Surabaya civil servants and (8) Bank Mandiri Surabaya as a state-owned company (BUMN) that has a CSR program. 
Figure 2. Research methodology

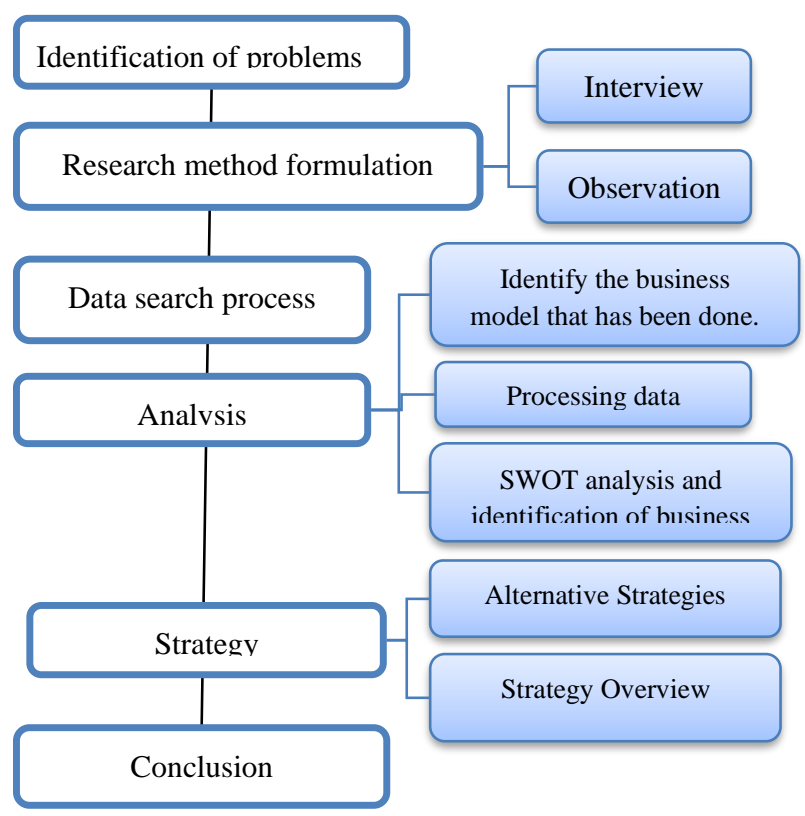

\section{RESULT}

Based on the data that have been obtained from interviews, it can be classified as follows:

TABLE 3. Result Indepth Interview

\begin{tabular}{|c|c|}
\hline Informant & Results \\
\hline Bang Jarwo & $\begin{array}{l}\text { - Bang Jarwo SME is still running } \\
\text { conventionally, legally the type of } \\
\text { company has not been formed. The } \\
\text { production site is carried out in a } \\
\text { contract house with a building area of } \\
\text { approximately } 45 \text { square meters. } \\
\text { - Tempe products that have been } \\
\text { developed into product variations such } \\
\text { as tempeh nuggets and tempeh chips. } \\
\text { - It has been selling tempeh since } 2014 \\
\text { after the closing of the brothels dolly in } \\
\text { Surabaya. } \\
\text { - Falling trips and experiencing losses did } \\
\text { not make Bang Jarwo give up selling } \\
\text { tempe. } \\
\text { The former branding of a mere tempe } \\
\text { brand, becoming Tempe bang Jarwo } \\
\text { because in } 2015 \text { was viral children's } \\
\text { "Adit Sopo Jarwo" movies, so the name } \\
\text { Jarwo is the same as the film's. } \\
\text { The production process using manual } \\
\text { milling machine and a small storage } \\
\text { rack. } \\
\text { In the production process, Bang Jarwo }\end{array}$ \\
\hline
\end{tabular}

and his wife are responsible for making the tempe.

- It is also limited capital and cash flow is still small.

- Distribution of product sales done around the village and offers on contact (link) through Whatsapp.

- During this time also still working with an online motorcycle to market its product tempe.

- Purchase of raw materials in soybean shop around West Surabaya and Sidoarjo, but more frequently in West Surabaya.

\section{Companion of $\bullet$ Bang Jarwo have a compelling story, of Dolly umkm someone who once naughty, now a hard- working person with selling tempe}

- We help Jarwo to do product branding and introduce it generally to the public

- Many city government people are interested in Bang Jarwo, because the product is delicious and the mayor's program also wants to introduce umkm products with various events in Surabaya.

- Lack currently at its production is still manual, due to space constraints, capital and tablespoons.

- We also help find students who want to study with Bang Jarwo to start a tempe business or just do an internship.

- We also plan to develop a variety of products in Bang Jarwo's tempe product by making the tempeh shape like fish, so the name of the product is "iwak tempe".

Domestic
customers

- Almost every day, there is always tempeh for the family's meal.

- Penyet tempeh food is still cheap and easy to make.

- We used to buy tempeh to the sale of vegetable or purchased on the market. Sometimes also buy at pitchman.

- Prices vary, some are cheap around Rp. 2,000 to Rp. 5,000 if you buy on the market.

- tempeh products actually become obligatory on the culinary food sales, because people are used to eating tempeh to use sambal.

- Customers also enjoy tempe food in the culinary delicacy of tempe penyet

- We buy tempeh cheap, because the customers also do not mind the brand tempeh, provided its tasty sauce.

Soybean traders
- Soybean prices fluctuate, it could rise and could go down, depending on the 
crop farmers in the village and seasonal conditions. During the rainy season, usually the harvest is also limited.

- If the buyer buys a small amount of soybeans, of course the price is rather expensive than buying a large quantity of soybeans.

- There are not many soybean sellers in Surabaya, perhaps only in large traditional markets that sell soybeans in large quantities, in traditional markets there may be a lot of processed soy products, namely tofu or tempeh that are sold.

\begin{tabular}{ll}
\hline $\begin{array}{l}\text { Student } \\
\text { organisation's }\end{array}$ & Interest in students today is high enough \\
& to create their own businesses or start- \\
& ups. \\
& Many students may not know more \\
& about the product tempeh Bang Jarwo, \\
& but some students may also know his \\
& tempeh products.
\end{tabular}

Dosen $\quad$ The prospectus aspect of the culinary business is very high, because this is a basic requirement of society, so many people choose the culinary business.

- Umkm in Dolly Surabaya needs to develop its business model and need assistance from the municipal government, so that the umkm existence there can still exist and can develop.

- Currently in Surabaya existing culinary event in the way of his Tunjungan every month. This is the moment to wake up to introduce umkm products in Surabaya as well as to attract people outside Surabaya to visit Surabaya.

$\begin{array}{ll}\begin{array}{l}\text { Surabaya civil }- \\ \text { servants }\end{array} & \text { Coaching for umkm business actors in } \\ & \text { Dolly has been carried out by the } \\ & \text { Surabaya municipal government. }\end{array}$

- The municipal government has also created a "mlaku - mlaku nang Tunjungan" program by inviting umkm in Surabaya.

- The public's interest in visiting Jalan Tunjungan is also high, an event that used to be only once a year on Surabaya's birthday, is now a monthly event of the Surabaya municipal government.

- $\mathrm{Bu}$ Risma (the mayor) also often orders food for meetings from umkm actors in Surabaya, this is also a support for umkm in Surabaya to keep going.
Bank Mandiri

- The Bank has also provided people's business credit (KUR) to support umkm in Surabaya.

- We also create CSR programs for certain parties in the umkm who need assistance to develop their business.

- It is not only the bank, other companies will also be allocated a budget of CSR, but allocations for each program a different company - different from one another.

Based on the collection of data analyzed in the SWOT quadrant, it can be seen that the results are:

Figure 4. SWOT quadrant

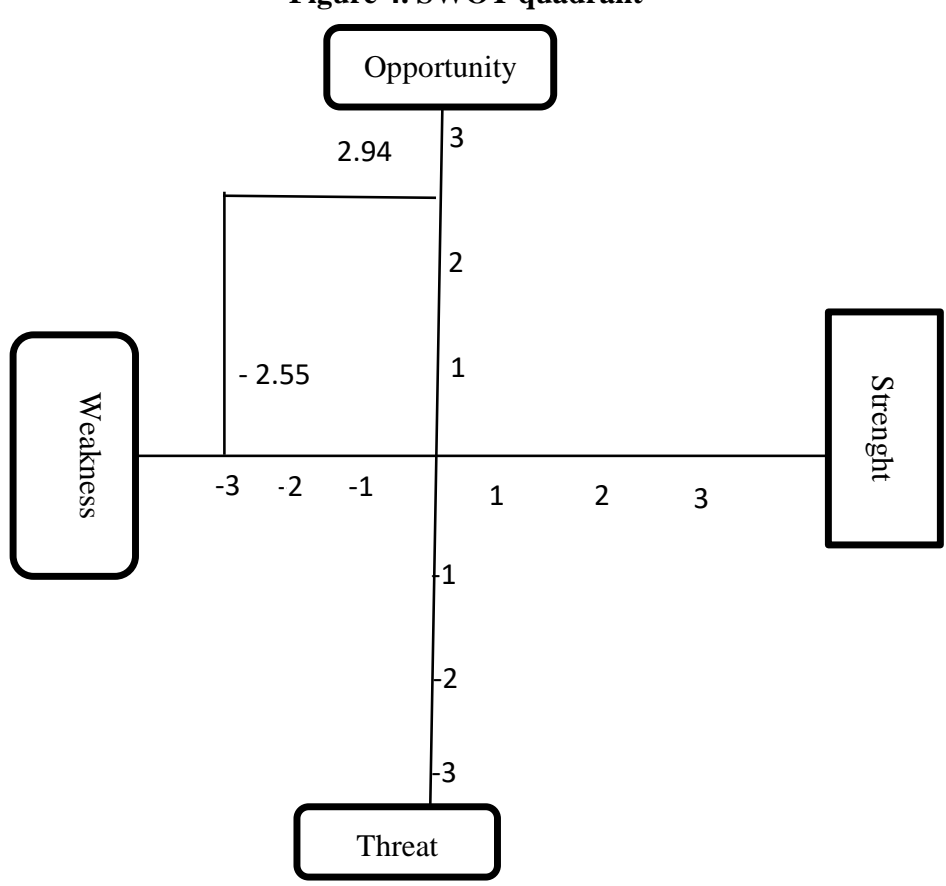

\section{DISCUSSION}

From the SWOT quadrant analysis, it is known that SMEs Bang Jarwo Tempe is in quadrant 3, which this business has a great opportunity, but there are still many problems from internal aspects that need to be fixed. In formulating a strategy for business development and improvement in SMEs of this tempe bang jarwo, using SWOT matrix analysis for reference decision making. 
TABLE 5. SWOT analysis

\begin{tabular}{|c|c|c|}
\hline IFAS & Strength (S) & Weakness (W) \\
\hline EFAS & $\begin{array}{l}\text { 1. Branding story the strong one } \\
\text { 2. Good taste and quality of tempe } \\
\text { 3. It has a tempe-based variant product. } \\
\text { 4. His skills and knowledge about tempe are very } \\
\text { good. } \\
\text { 5. Bang Jarwo has the characteristics of hard work } \\
\text { and painstaking. }\end{array}$ & $\begin{array}{l}\text { 1. Small production site } \\
\text { 2. Using a manual grinding machine } \\
\text { 3. Limited storage shelf for tempe } \\
\text { 4. Limited sdm } \\
\text { 5. Low capital and cash flow } \\
\text { 6. Small distribution network } \\
\text { 7. Business legality has not been PT / CV. }\end{array}$ \\
\hline Opportunity (O) & $\mathrm{SO}$ & WO \\
\hline $\begin{array}{l}\text { 1. Government assistance in city events } \\
\text { 2. There are links with government institutions } \\
\text { and BUMN offices. } \\
\text { 3. There are community social institutions } \\
\text { 4. There are young students } \\
\text { 5. There is a network of a greengrocer in the } \\
\text { market and around. } \\
\text { 6. There is an online network via motorbike } \\
\text { taxi and grab }\end{array}$ & $\begin{array}{l}\text { 1. Cooperating with the municipal government and } \\
\text { other municipal government service institutions in city } \\
\text { events. } \\
\text { 2. Conducting promotions, production training } \\
\text { workshops, and introducing tempe products to the } \\
\text { public and students. }\end{array}$ & $\begin{array}{l}\text { 1. Adding online and offline distribution } \\
\text { networks. } \\
\text { 2. Submission of CSR for production equipment } \\
\text { and equipment to city government institutions or } \\
\text { BUMN offices. } \\
\text { 3. Licensing the manufacture of PT with the help } \\
\text { of the city government. }\end{array}$ \\
\hline Threat (T) & ST & WT \\
\hline $\begin{array}{l}\text { 1. Price competition and high quality of tempe. } \\
\text { 2. New competitors are easy to emerge } \\
\text { 3. High tempe product substitutions } \\
\text { 4. High consumer power } \\
\text { 5. High supplier strength }\end{array}$ & $\begin{array}{l}\text { 1. Modification of packaging, price, and weight of } \\
\text { tempe. } \\
\text { 2. Optimizing the Bang Jarwo brand as a dolly } \\
\text { citizen who wants to change. }\end{array}$ & $\begin{array}{l}\text { 1. Maintain production capacity and quality by } \\
\text { looking for alternative suppliers. }\end{array}$ \\
\hline
\end{tabular}

From the analysis of the internal and external aspects above, several strategies are produced, including:

1. Cooperating with the municipal government and other municipal government service institutions in city events.

2. Conducting promotions, production training workshops, and introducing tempe products to the public and students.

3. Adding online and offline distribution networks.

4. Submission of CSR for production equipment and equipment to municipal government institutions or BUMN.

5. Licensing the manufacture of PT with the help of the city government.

6. Modification of packaging, price, and weight of tempe.
7. Optimizing the Bang Jarwo brand as a dolly citizen who wants to change.

8. Maintain production capacity and quality by looking for alternative suppliers

From the analysis of the internal and external aspects above, several strategies are produced, including:

1. Cooperating with the municipal government and other municipal government service institutions in city events.

2. Conducting promotions, production training workshops, and introducing tempe products to the public and students.

3. Adding online and offline distribution networks.

4. Submission of CSR for production equipment and equipment to municipal government institutions or BUMN. 
5. Licensing the manufacture of PT with the help of the city government.

6. Modification of packaging, price, and weight of tempe.

7. Optimizing the Bang Jarwo brand as a dolly citizen who wants to change.

8. Maintain production capacity and quality by looking for alternative suppliers.

From the strategies above, the authors formulate a combination of strategies into four canvas business model designs with nine blocks for Bang Jarwo Tempe SMEs, namely:

1. The focus of increasing sales of tempe and other product variations is to the institutional, household, and pengetan traders segment.

2. Create workshops and training in making tempe and tempe business.

3. Make telling stories in the form of books and t-shirts.
4. To become a place for distributing CSR for government, state-owned and private institutions.

The details of the canvas model business can be described as follows:

a. Focus on selling tempe and other product variations;

The tempe business is the sale of tempe along with variations of tempe products which sales are still being increased on a larger scale by covering a wider target market, not only the household market segment but also traders \& employees of government institutions, adding online and offline channel distribution, build personal relationships with customers, collaborate with other suppliers, increase human resources and optimize existing capacity in the form of quantity \& quality of production.

Figure 6. Business Model Canvas Strategy to Focus On Selling Temp

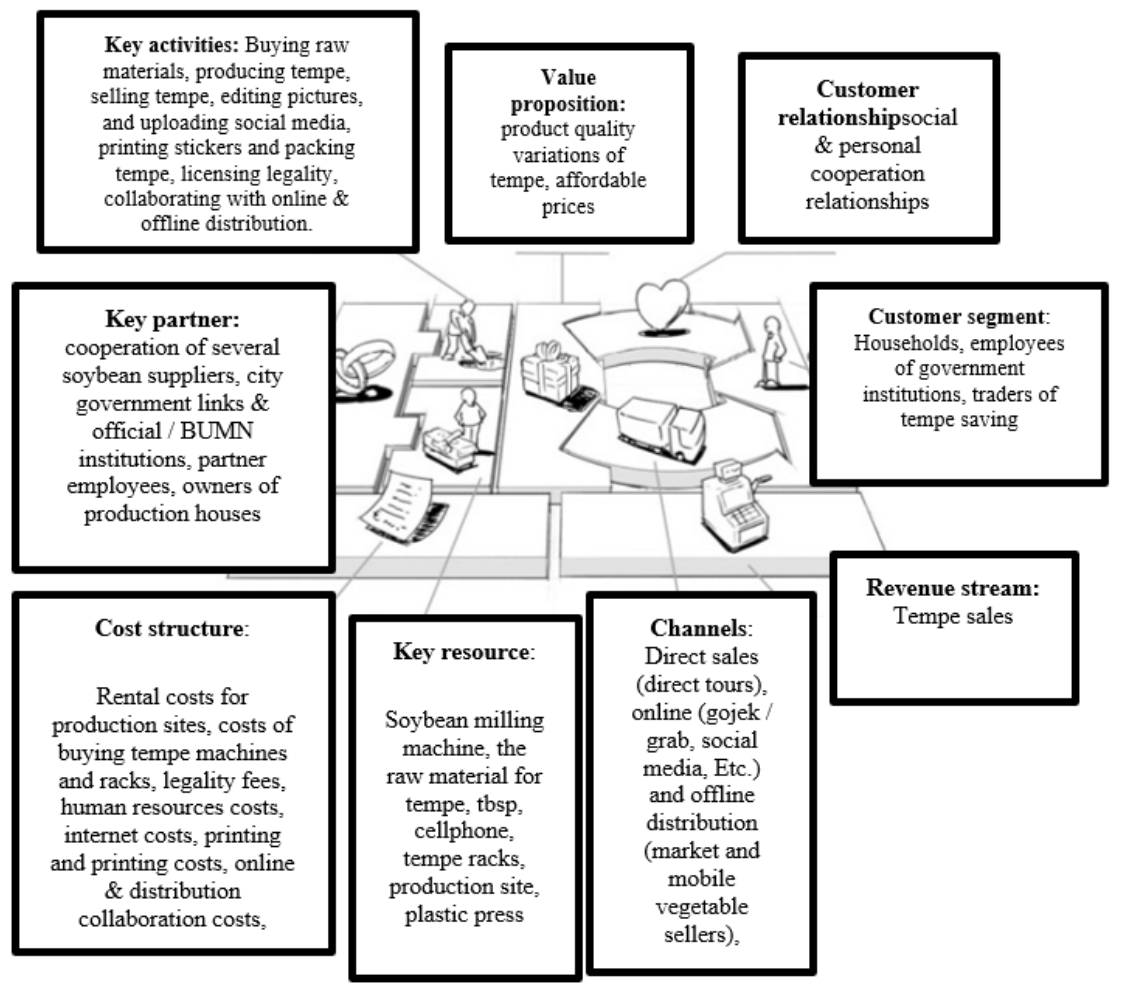


b. Create workshops and training in making tempe and its business.

When core business on going well, the enterprise can make new product development and manage the develop process to increase profit (Kottler and Keller 2016). This business is a development of the main business (selling tempe), which can be optimized because Bang Jarwo has an interesting historical story with his skills in making tempe and his growing business processes. This workshop and training aim to socialize making tempe to homemakers and how to do tempe business to students and sell these tempe products.

Figure 7. Business Model Canvas workshop and training strategy

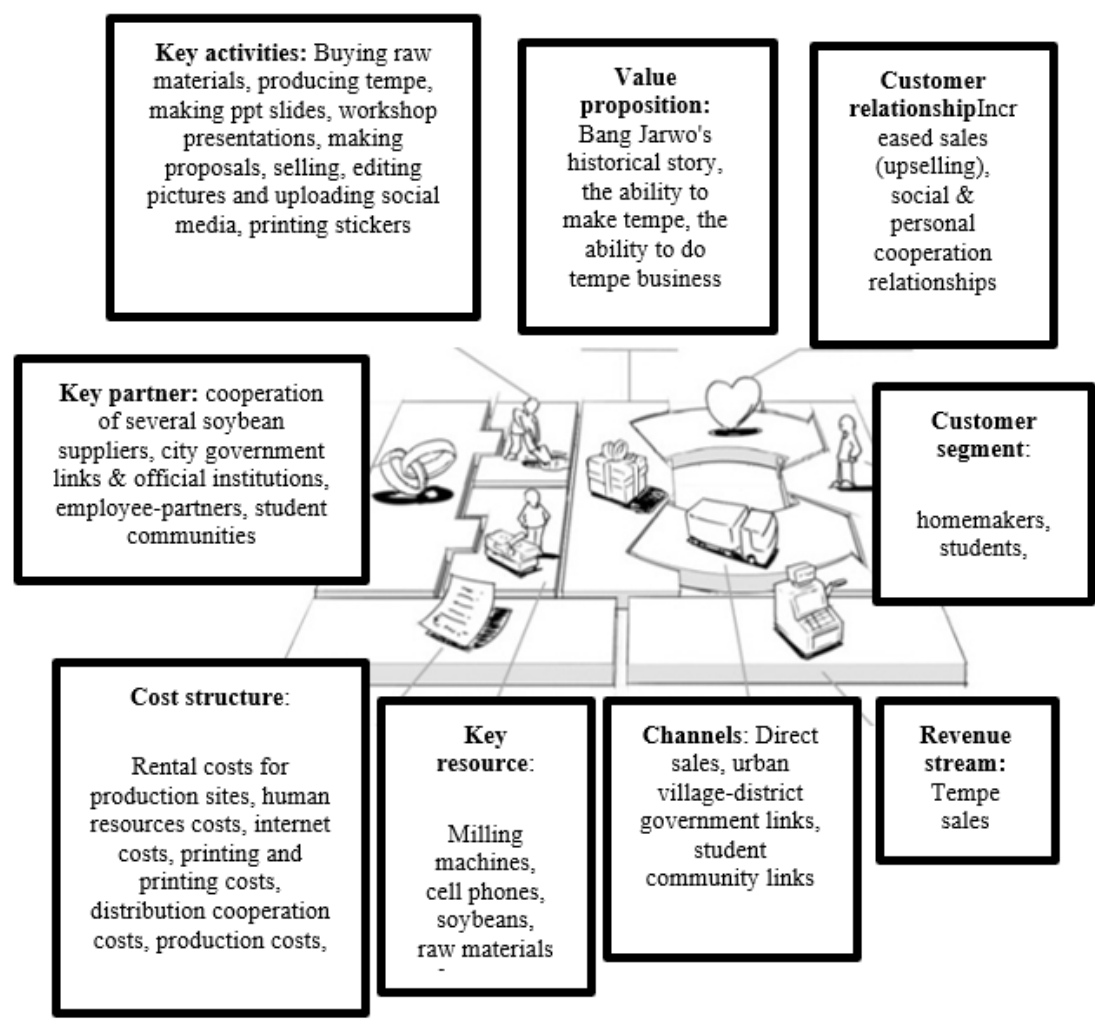

c. Make telling stories in the form of books is the way to make Bang Jarwos's business and t-shirts.

This business is the development of selling tempe, which will add value to Bang Jarwo's branding. The historical story of Bang Jarwo's life can be developed to write a biography that can be printed in book form and then sold in the wider community as a book. One of the way to build brand identity is story telling in media (David W. Cravens, Nigel F. Piercy 2013). Make telling story in the form of books and t-shirt 
Figure 8. Business Model Canvas Strategy Telling The Story In Book Form

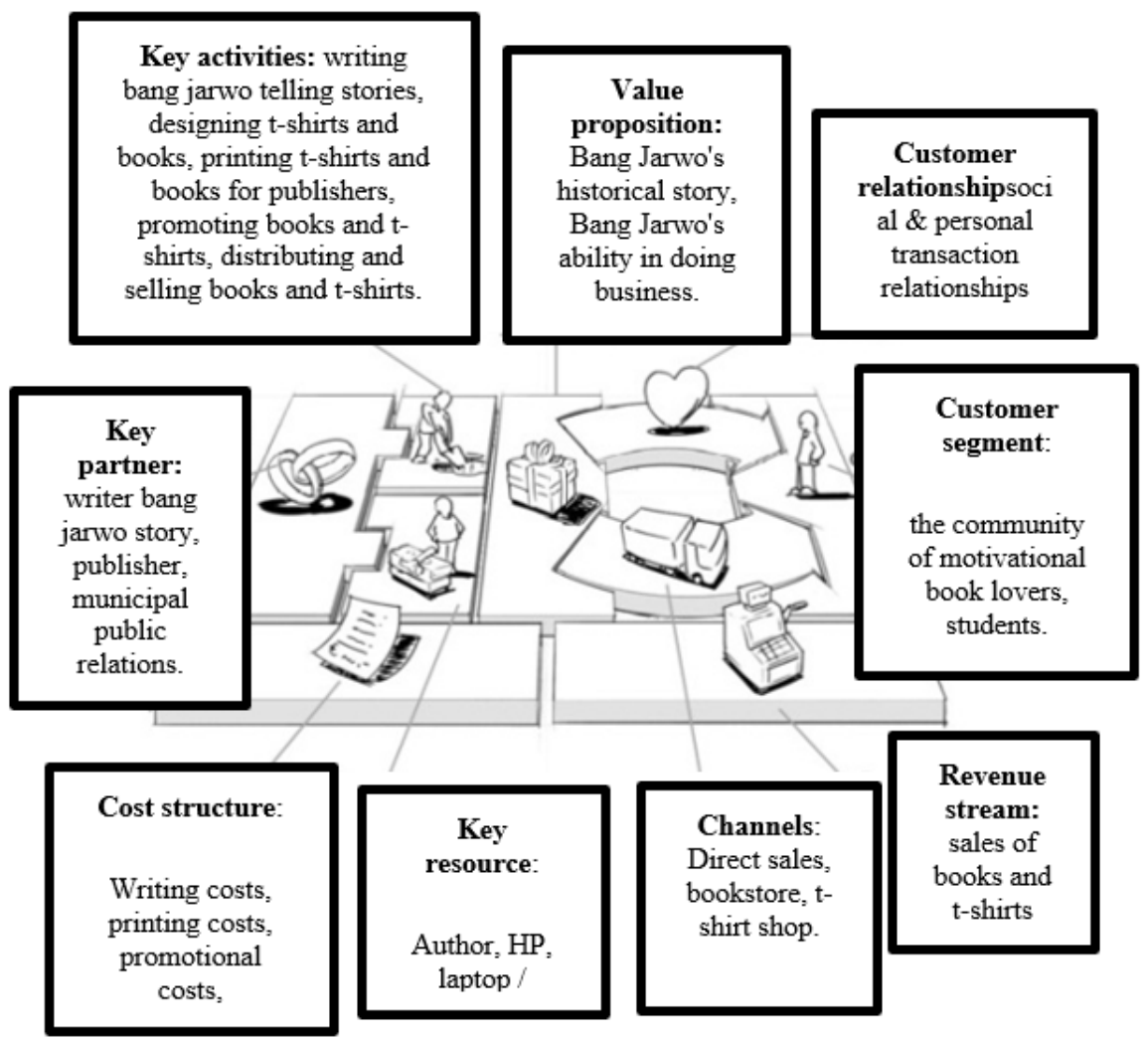

d. Make it a place for distributing CSR for government, state-owned and private institutions.

There is a need for improvement in the internal aspect because seeing the position of Jarwo's business, which has many weaknesses (weakness), requires large funds to survive in business competition. With Bang Jarwo's tempe business that continues to grow, he has created a business model as a medium for receiving grants and CSR disbursements from government institutions and BUMN. Some big company or institutions will spend theirs profit for CSR to help some people or MSME, and this is opportunity for Bang Jarwo's tempe business to get CSR. CSR program that use some company will get good brand equity and firm performance (Rahman, Rodríguez-Serrano,

and Lambkin 2019), so this is opportunity for Bang Jarwo's business to get CSR for many companies. 
Figure 9. Business Model, The Strategy Canvas Makes CSR Channeling Places

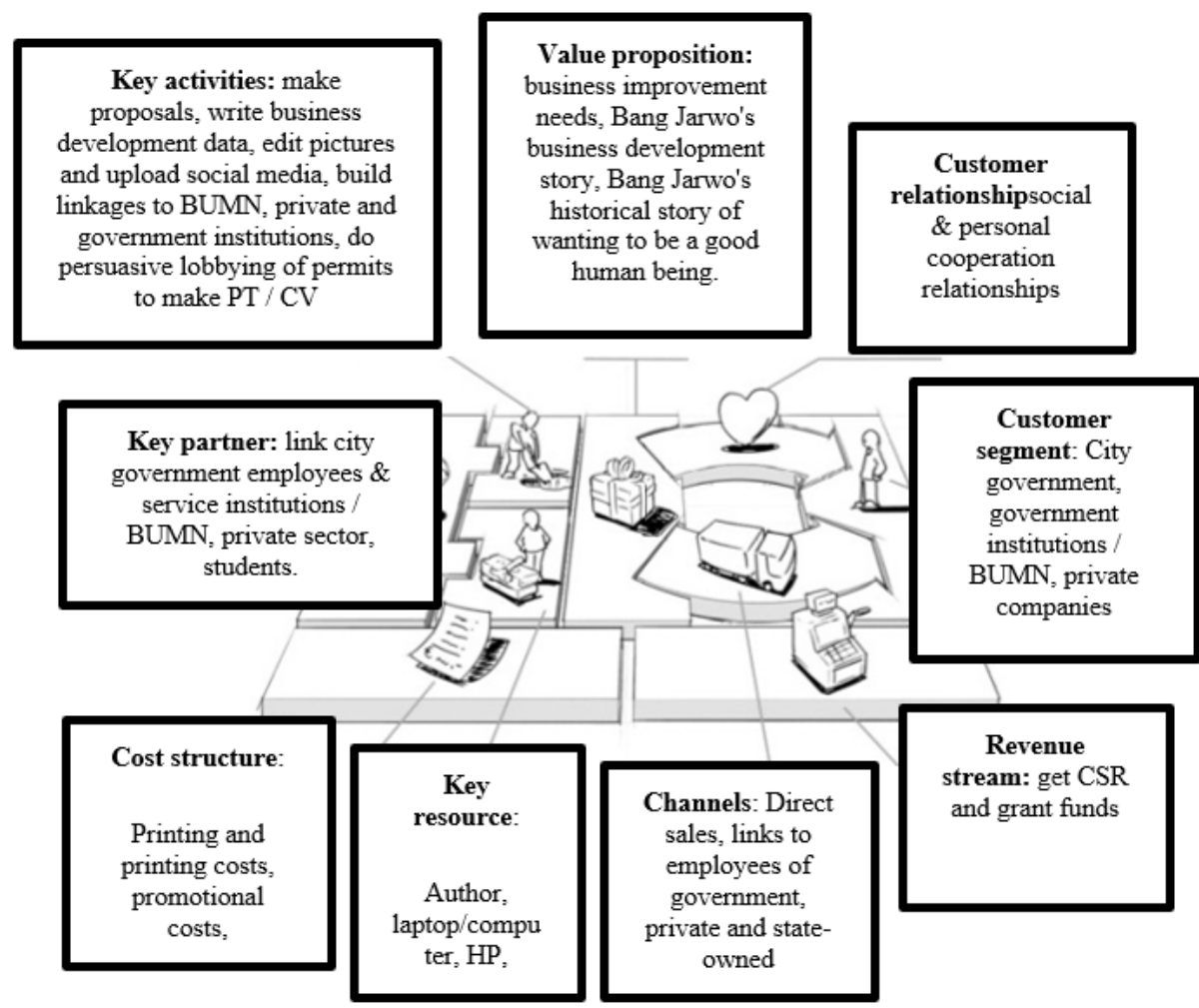

\section{CONCLUSSION}

Based on the observations, the data analysis process above, the conclusions of the canvas business model strategy for Bang Jarwo SME obtained in this study are as follows:

1. Focus on selling tempe and other product variations.

2. Create workshops and training in making tempe and its business

3. Make a telling story in book form.

4. To make CSR channeling for government, BUMN, and private institutions.

\section{BIBLIOGRAPHY}

Ayodya, Wulan. 2020. UMKM 4.0. Edited by Dionisia Putri. Jakarta: PT. Elex Media Komputindo.

David W. Cravens, Nigel F. Piercy. 2013. Strategic Marketing. Tenth Edit. Singapore: McGraw-Hill Education.
Hakim, Abdul. 2014. TRI RISMAHARINI. Edited by Daniel Bukit. 1st ed. Surabaya: PT. Zaytuna Ufuk Abadi.

Kottler, Philip, and Kevin Lane Keller. 2016. Marketing Management. Edited by Stephanie Wall. Global Edi. Harlow: Pearson Education Limited.

Marfuah, Umi, Rina Nopianti, and Ambaria. 2019. "Business Development Strategy with Business Model Canvas Approach at Pakdhe Mie Chicken ShopCimanggis, Depok." International Journal of Scientific and Technology Research 8 (2): 44-49.

Neuman, William Lawrence. 2003. Social Research Method, Qualitative and Quantitative Approach. 7th Editio. Boston: Pearson Education Limited.

Osterwalder, Alex, Yves Pigneur, Greg Bernanda, and Alan Smith. 2019. Value Proposition Design. Jakarta: PT. Gramedia. 
Osterwalder, Alexander, and Yves Pigneur. 2012. Business Model Generation. Jakarta: PT. Gramedia.

Rahman, Mahabubur, M. Ángeles RodríguezSerrano, and Mary Lambkin. 2019. "Brand Equity and Firm Performance: The Complementary Role of Corporate Social Responsibility." Journal of Brand Management 26 (6): 691-704. https://doi.org/10.1057/s41262-01900155-9.

Rangkuti, Freddy. 2006. Analisis SWOT Teknik Membedah Kasus Bisnis. Jakarta: PT. Gramedia Pustaka Utama.

—. 2015. Personal SWOT Analysis. Jakarta: PT. Gramedia Pustaka Utama.

Sudrajat, Jajat, Muhammad Ali Rahman, Glory A. Guzman, Michael Yoseph Ricky, and Agung Hari Sasongko. 2018. "Innovation of Entrepreneurship Learning with Business Model Canvas Game." International Journal of Entrepreneurship 22 (3): 1-12.

Sugiyono. 2010. Metode Penelitian Pendidikan Pendekatan Kuantitatif, Kualitatif, Dan R\&D. Bandung: Alfabeta.

Tambunan, Tulus T.H. 2019. "The Impact of the Economic Crisis on Micro, Small, and Medium Enterprises and Their Crisis Mitigation Measures in Southeast Asia with Reference to Indonesia." Asia and the Pacific Policy Studies 6 (1): 19-39. https://doi.org/10.1002/app5.264.

Umar, Abdullah, Agung Hari Sasongko, Glory Aguzman, and Sugiharto. 2018. "Business Model Canvas as a Solution for Competing Strategy of Small Business in Indonesia." International Journal of Entrepreneurship 22 (1): 1-9.

Zikmund, William G. 2013. Business Research Method. United State: South- Western. 